\title{
NEW TECHNOLOGIES IN BIOMEDICINE. OPINIONS OF YOUNG ROMANIAN PHYSICIANS
}

\author{
Sorin Hostiuc ${ }^{1}$, Octavian Buda 2 , Claudia Ileana Mihailov³, Mihaela Hostiuc ${ }^{2}$
}

\begin{abstract}
The purpose of this article is to summarize the way young medical professionals view these modern biomedical procedures and their moral acceptability. Materials and methods: A survey, filled in online, analyzing items in four main areas: genetic techniques, cloning, stem cell research, and assisted reproduction. Results: Most subjects agreed that the right to the genetic material should be a fundamental human right and that genetic engineering should be used if it could lead to the elimination os severe genetic diseases like cystic fibrosis and thalassemia. The least acceptance rate was obtained for techniques that would either change physical traits (like eye or hair color) or augment them. Most subjects agreed that the prenatal screening should be mandatory, and if the screening detects a severe congenital malformation the physician should recommend therapeutic abortion. Most subjects disagreed that cloning of any type, either therapeutic or reproductive, using human, animal, or vegetal genetic material. Most subjects agreed with the collection and storage of cord blood stem cells and the use of adult stem cells, and most of them disagreed with the creation of embryos specifically for obtaining stem cells. Conclusions: Even if the national legislation in this area is very scarce, the responses have usually identified the highly controversial techniques. If however the national legislation has elements similar to the items from the survey, they tended to take the respective items as morally acceptable without trying to analyze them critically.
\end{abstract}

Key words: genetic, cloning, stem cell research, assisted reproductive techniques

\section{Nuevas tecnologías en biomedicina. Opiniones de médicos jóvenes de Rumania}

Resumen: El propósito de este artículo es conocer la forma en que jóvenes profesionales médicos ven los procedimientos biomédicos modernos y su aceptabilidad moral. Materiales y métodos: Una encuesta, rellenada online, que analiza elementos en cuatro áreas principales: técnicas genéticas, clonación, investigación con células madre y reproducción asistida. Resultados: La mayoría de los sujetos acepta que el derecho a material genético debería ser un derecho humano fundamental y que la ingeniería genética debería usarse si pudiese eliminar enfermedades genéticas severas, como la fibrosis quística y la talasemia. Se obtuvo una frecuencia de aceptación menor para técnicas que pudieran o cambiar características físicas (como el color de los ojos o del pelo) o aumentarlas. La mayoría de los sujetos acepta que el examen de detección prenatal debiera ser mandatorio y si se detecta una deformación congénita severa, el médico debería recomendar aborto terapéutico. La mayoría de los sujetos no acepta clonación de ningún tipo, terapéutica o reproductiva, usando material genético humano, animal o vegetal. La mayoría de los sujetos acepta recoger y almacenar células madre del cordón umbilical y el uso de células madre adultas y está en desacuerdo con la creación de embriones específicamente para obtener células madre. Conclusiones: aunque la legislación nacional en esta área es muy escasa, las respuestas por lo general han identificado las técnicas altamente controversiales. Sin embargo, si la legislación nacional tiene elementos similares a los temas de la encuesta, se tiende a tomarlos respectivamente como moralmente aceptables sin tratar de analizarlos críticamente.

Palabras clave: genética, clonación, investigación con células madre, técnicas de reproducción asistida

\section{Novas tecnologias em biomedicina. Opinióes de jovens médicos romenos}

Resumo: Objetivo. A proposta deste artigo é sumarizar o modo de ver dos jovens profissionais médicos sobre procedimentos biomédicos modernos e sua aceitação moral. Materiais e métodos. Uma pesquisa de opinião realizada online, analisou ítens de quatro principais áreas: técnicas genéticas, clonagem, pesquisa com células-tronco, e reprodução assistida. Resultados. Itens relacionados à Genética. A maioria dos sujeitos concordaram que o direito ao material genético deveria ser um direito humano fundamental e que a engenharia genética poderia ser usada se puder levar à eliminação de doenças genéticas severas como a fibrose cística e a talassemia. A menor taxa de aceitaçáo foi obtida para técnicas que pudessem modificar o aspecto físico individual (como olho e cor do cabelo) ou aumentá-los. Técnicas de reprodução assistida. A maioria dos sujeitos concordaram que a seleção pré-natal (screening) deverá ser impositiva, e que se o "screening" detetar uma severa malformação congênita o médico deveria recomendar o aborto terapêutico. Clonagem. A maioria dos sujeitos discordaram da clonagem de qualquer tipo, terapêutica ou reprodutiva, com material genético de uso humano, animal, ou vegetal. Pesquisa com células-tronco. A maioria dos sujeitos concordaram com a obtenção e estocagem de células-tronco de sangue do cordão umbilical e a utilização de células-tronco adultas, e a maioria deles discordaram da criação de embrióes especificamente para a obtenção de células-tronco. Conclusões. Mesmo que a legislação nacional na área seja muito escassa, as respostas usualmente identificaram as técnicas como altamente controversas. Quando a legislação nacional oferece elementos semelhantes aos ítens obtidos pela pesquisa de opiniáo, eles tenderiam a tomar os respectivos ítens como moralmente aceitáveis sem tentar analisá-los criticamente.

Palavras-chave: genética, clonagem, pesquisa com células-tronco, técnicas de reprodução asssitida

${ }^{1}$ Centre for Advanced Studies in Bioethics and History of Medicine, Bucharest, Romania

Correspondence: sorin.hostiuc@umf.ro

${ }^{2}$ Carol Davila University of Medicine and Pharmacy, Dept. of History of Medicine Bucharest, Romania

${ }^{3}$ Department of Medical Semiology, Faculty of Medicine, Ovidius University of Constanta Clinical Port Hospital of Constanta, Romania 


\section{Introduction}

Debates in human genetics and its associated ethical issues and controversies are a global phenomenon, taking place in the context of local and regional contexts, either medical, legislative, or philosophical(1). Biomedical ethics in the countries from the European Union is regulated through international and national regulations. Most important international ethical regulations in medicine and biomedical research in EU countries are nowadays the Universal Declaration on Bioethics and Human Rights, drawn by the United Nations Educational, Scientific and Cultural Organization (UNESCO), the International Ethical Guidelines for Biomedical Research Involving Human Subjects, adopted by the Council for the International Organizations of Medical Sciences (CIOMS) and WHO, the Declaration of Helsinki (currently the Cairo revision), and the European Convention for the Protection of Human Rights and Dignity of the Human Being with regard to the Application of Biology and Medicine (Oviedo Convention) with its additional protocols. Each EU country has in turn specific national regulations and norms(2). In former communist countries from the Eastern block, the transmission of the principles presented in EU and other international norms regarding medical ethics, ethics in medical research and human rights in general has proven to be mostly mimetic - the norms and principles were taken as they were, usually without a proper public debate or an input from medical professionals. Millard for examples, in an article reviewing the way Oviedo Convention was ratified by various former communist countries identified an increased mimesis and passivity in the analysis of the document before ratification(3). In Romania, Millard identified a completely formal ratification of the Convention - both the Senate and the National Assembly ratified both the Convention and its cloning protocol with unanimous voting, without any commentaries from the internal committees reviewing it before ratification (Judicial Committee, Discipline and Immunities Committee, Committee for Human Rights, Religion, and National Minorities, and Committee for Health and Family)(3).
Without a proper public debate, and without taking into consideration the local cultural, social and economical context, many ethical principles are difficult to implement by local medical professionals $(4,5)$. This process of mimesis is known in Romania as the theory of forms without substance $(6,7)$. This approach may allow a formal alignment to the Western, democratic principles, but the core is not understood correctly or completely, or even forgotten in clinical practice(5). If when there are clear national regulations, they are obeyed for fear of legal consequences $(8,9)$, in cases where these are absent there is an increased risk for non-ethical behaviors (10). This is the case with new, emerging technologies like genetic engineering, assisted reproductive techniques, or stem cell research, for which the legislation is mostly absent (or when present is very general, or without specific implementing rules).

The purpose of this article is to summarize the way young medical professionals view these modern biomedical procedures and their moral acceptability, as they are the ones who will be, in a few years, on the verge of implementing (or not) many of these techniques. The study analyzed four main areas: genetics, cloning, stem cell research, and assisted reproductive technologies.

\section{Materials and methods}

The study was conducted during a Bioethics module. In Romania, the residency training has a variable period (from three years for Family Medicine/General Practitioners to seven years in Neurosurgery), and a two weeks or one month Bioethics module is mandatory during this period. The completion of the questionnaire was anonymous. The items we chose for this study were generated by discussions with young physicians during their Bioethics module in previous years; we therefore chose not to take an international, validated survey form as none was close enough to our specific needs (to test the views on a large number of issues, to be short, and to include data about the items that were deemed most interesting by the participants from the previous years).

The questionnaire consisted of 29 statements for which the respondents had to give a grade from zero to ten (an eleven points Likert scale), 0 mea- 
ning completely disagree, 1-3 moderately disagree, 4-6 neutral, 7-9 moderately agree, and 10 strongly agree with the corresponding statement. The Institutional Review Board approved the stu$\mathrm{dy}$, and the consent was presumed (filling up the questionnaire was optional). The items were divided into four main groups: statements about genetic engineering, cloning, assisted reproduction, and stem cells. A distribution of the respondents according to their institution and specialty was not assessed, as it could be used to identify the respondents. The questionnaire was built using Moodle CMS 2.1, exported in a .csv file and then imported in a.sav database. Statistical analysis was conducted using SPSS v.20 for Mac.

Descriptive statistics was conducted using the SPSS "frequencies" function (mean, median, standard deviation,). Testing for significant differences between groups was conducted using ANOVA table. Correlation between variables was conducted using the Spearman correlation coefficient. A p value below .05 was considered statistically significant and a $\mathrm{p}$ value below .001 was considered highly significant.

\section{Results}

A total number of 153 medical residents agreed to be included in the study out of the 289 who participated in that specific module (a response rate of $53 \%)$, of which $125(81.7 \%)$ were women and $28(18.30 \%)$ were men. The mean age for men (30.8 years) was significantly higher compared to the mean age of women that was 28.8 (ANOVA test, $\mathrm{F}=12.777, \mathrm{p}<.001$ )

\section{Genetic items}

A total number of 12 items analyzed the opinions of young physicians regarding genetic ethical issues. Most subjects agreed that the right to the genetic material should be a fundamental human right and that genetic engineering should be used if it could lead to the elimination os severe genetic diseases like cystic fibrosis and thalassemia. The least acceptance rate was obtained for techniques that would either change physical traits (like eye or hair color) or augment them. See Table 1 for details.

\section{Assisted reproductive procedures}

A total number of five items analyzed the opinions of young physicians regarding genetic ethical issues. Most subjects agreed that the prenatal screening should be mandatory, and if the screening detects a severe congenital malformation the physician should recommend therapeutic abortion. Most subjects disagreed with sex selection by prenatal screening followed by selective abortion of the fetus (See Table 2 for details).

\section{Cloning}

A total number of six items analyzed the opinions of young physicians regarding cloning. Most subjects disagreed that cloning of any type, either therapeutic or reproductive, using human, animal, or vegetal genetic material. There are significant differences between genders regarding therapeutic cloning using animal eggs in which to insert human genetic materials, case in which men favored the procedure (with a mean of 1.57, compared with 0.74 for women), and highly significant differences between genders regarding the permissibility of animal reproductive cloning, case in which men preferred it (with a mean score of 3.64, compared with 1.55 for women). The increase in age was negatively correlated with the acceptance of the permissibility of animal cloning, therapeutic cloning using animal eggs, and reproductive cloning in humans using only the couple's genetic material. (See Table 3 for details)

\section{Stem cells}

A total number of six items analyzed the opinions of young physicians regarding stem cell research. Most subjects agreed with the collection and storage of cord blood stem cells and the use of adult stem cells, and most of them disagreed with the creation of embryos specifically for obtaining stem cells. The collection of stem cells from aborted embryos was accepted significantly easier by older residents, whilst creating embryos for the purpose of collecting stem cells and donor babies was accepted more easily by younger residents (see Table 4 for details). 


\section{Discussions}

Studies analyzing the views of physicians (or young physicians regarding the new technologies) were not done, to our knowledge in Romania. Moreover, as presented in the Introduction section, the legislative process that ratified the Oviedo Convention and the Cloning protocol in Romania went smoothly, without any real discussions, public debates, or opposing opinions. This lead to a formal acceptance of the protocol, without being obtained a feedback from the persons who were asked to implement it. Subsequently the issues associated with modern, emerging medical techniques such as stem cell research, cloning, or genetic engineering remained largely un-debated and the physicians did not really understood their associated moral issues, especially as most of them were seen as only theoretical.

A 1990 European public opinion poll including 3156 respondents from the U.K., France, Italy and Germany regarding biotechnologies considered as the most important benefit generated by them to be the cure of serious diseases. Their largest concern was eugenics, followed by environmental harm, and potential health hazards from laboratory genetic research(11). In the 2000's, when genetic engineering was already mainstream, it was perceived as being associated with a high lack of trust in both the science behind it and the policies implemented to enable sufficient and efficient regulations of this field(12). Our study has similar results, the only accepted engineering technologies being the ones addressing severe, potentially lethal genetic diseases, for which no known cure was identified (a mean score of 8.33 and a median of 10). For multifactorial diseases like hypertension or diabetes the respondents were mostly in agreement that they should not be used (a mean score of 3.59 and a median score of 3). All other enhancement techniques were viewed very skeptically, with score of below 2. These scores suggest a good understanding of the consequences of genetic engineering techniques and a good evaluation of the risk-benefit ratio. Also, associated with a high acceptance of the fact that genetic material should be a fundamental human right, lead to a conservative approach to genetic engineering, in accordance with Art 13 of the Oviedo Convention: "An interven- tion seeking to modify the human genome may only be undertaken for preventive, diagnostic or therapeutic purposes and only if its aim is not to introduce any modification in the genome of any descendants" (13). When however these techniques are the only ones able to provide a medical benefit they are accepted, as the potential risks associated with them (from the uncertainty associated with possible individual consequences caused by altering the human genome to social and international consequences(14-16)) are with certainty smaller than the certainty of the unfavorable prognosis associated with them. Taking into consideration the low acceptance rate for genetic engineering, the respondents did not consider the state to be required to pay for these techniques (a mean score of 1.43 and a median of 0 ). Moreover, they did not agree with the private financing of genetic engineering (a mean score of 3.08 and a median of 1), an action that would most likely cause significant disparities between the those who can pay for them and those who can't(14).

Genetic tests for various disease have already entered clinical practice, and their general acceptability is less debatable. There are however a few controversial areas such as the three itemized in our survey. As a mean (5.91, with a median of 5) the respondents were mostly neutral regarding genetic tests that could be considered as discriminative. However, almost one third gave a score of 10 , therefore strongly disagreeing with this type of genetic testing. The use of genetic information for insurance purposes is viewed as highly controversial (a mean score of 2.75 and a median score of 0 ). In Romania the healthcare system is publicly financed, and therefore the use of genetic tests as a mean of increasing insurance rates(17-20) is a non-issue. The high rebuttal rate suggests either a strong attachment to the principle of medical confidentiality, or a good knowledge of the ethical issues from other countries or, most likely, the presence of a good moral compass. Informing the families is a member is found positive for a genetic disease that has the potential to affect other family members as well is also regarded, as a mean, as neutral (a mean score of 4.31 and a median of 5). However, it we analyze the distribution of the responses we will identify almost one third of respondents (50) highly disagreeing and about one quarter (32) highly agreeing with statement. The 
disagreement is most likely caused by the mandatory aspect of the professional secret (including in relation with the families, as this is specifically stated in the Deontology Code of the Romanian College Board). The respondents highly agreeing with the breach of medical confidentiality consider the potential consequences of not disclosing the information - both medical, for the family members $(21,22)$ and legal - for example in the US there have been cited lawsuits initiated for a non-disclosure of a potentially life threatening genetic disease or predisposition(23).

By analyzing the reproductive items in our survey, the most striking element is the extremely high approval rate of prenatal screening; moreover, they considered that the physician has a duty to recommend therapeutic abortion (both statements having a median value of 10). Prenatal screening per se is associated a lot of ethical dilemmas, in which are included: the possibility of a false positive test, leading to a therapeutic abortion of a normal child, the fact that approving therapeutical abortion may be considered, for other persons living with that disability, a form of discrimination, the fact that physicians, through their recommendations and actions may decide who lives and who dies, and so on(24). Prenatal screening is a procedure that is in general highly accepted by the physicians in Romania, as it was shown in a previous study, conducted two years before this one(25), even if they are aware that the procedure can be considered eugenic. The most likely cause is the need for the physicians to rest assured that the child is born without genetic diseases, as their presence may lead to severe judicial consequences, even if the prenatal care was done according to the guidelines. There have been cases in which Romanian physicians were accused by the parents for negligence in cases in which the parents themselves haven't obeyed the physician's recommendations regarding prenatal care and follow-ups, or have done prenatal tests much later than normal(26). Prenatal screening followed by therapeutic abortion is viewed much lightly if done for genetic disease (mean of 7.73 and a median of 10) than for sex selection (mean of 0.45 and a median of 0 ). If prenatal screening identifies a congenital malformation, the respondents considered the physician to have a duty to recommend therapeutic abortion. Again, this shows a good moral compass - the permissibility of prenatal screening without giving the option to safely perform the abortion may lead for the affected women to chose between giving birth to a child with a severe adaptation deficit, or perform the abortion in non-safe environments, a true medical hazard(27-31). The item regarding the right to reproduction of psychiatric patients and those with severely diminished mental capacity was inserted to test the mimesis of the respondents. In Romania, the Family Code specifies that psychiatric patients with severely diminished mental capacity are not allowed to get marry. Knowing the law, they considered normal the statement, without analyzing it, suggesting once again the fact that many ethical norms are taken per se, without a discriminative analysis, a similar to the one done in Romanian parliament regarding the ratification of Oviedo Convention(3).

Cloning is worldwide a highly controversial technique, and is not usually accepted for humans. For example in a study conducted in Germany with women as respondents, over $82 \%$ opposed reproductive cloning(32); another one, conducted also in Germany with scientists as respondents showed an overall rebuttal rate for cloning of $79 \%$, and an approval rate for therapeutic cloning of only $19 \%$ (33). Our study showed an overall disapproval of all kinds of cloning from human (either therapeutic or reproductive), animal or vegetal. If in regard of human cloning the attitude is normal, regarding animal and vegetal, the disapproval rate was unexpected. Reasons for this disapproval rate may be the power of the "cloning" keyword - its use is associated with something bad, or an increased awareness about genetically engineered food.

Regarding stem cells, most subjects approved the use of adult stem cells and collection of cord blood stem cells. Both techniques are indeed associated with a low number of ethical dilemmas, even though the usefulness of collection and storage of cord blood stem cells is debatable in its current form(34). Donor babies are regarded with indulgence, a majority favoring them (mean of 6.37 and a median of 8). This attitude may again be viewed as mimetic - Romanian law allows bone marrow transplant from minors (the only accepted form of transplant from living do- 
nors)(35). Therefore, the subjects had associated the item with the legal norm and did not analyzed it further. The lowest acceptance rates were obtained for creating embryos for harvesting stem cells (with a mean of 2 and a median of 0 ), and creating clones for harvesting stem cells (with a mean of 3.24 and a median of 1 ). Both techniques are highly controversial and not allowed in most countries with a specific law in this area(36-38).

\section{Limits of the study}

As the number of items was quite large, there is a chance of a Type I statistical error affecting some of the statistical tests conducted.

There is a disproportion between men and women subjects that responded to out survey; however, this distribution on genders is similar to the one found in Romanian medical schools.

The use of a non-validated questionnaire; even if the questionnaire was not properly validated, the purpose of the study, to identify the way young physicians view these modern techniques, was reached. Moreover, there were no problems with the understanding of the items from the questionnaire.

\section{Conclusions}

Even if the national legislation in this area is very scarce, the responses have usually identified the highly controversial techniques. If however the national legislation has elements similar to the items from the survey, they tended to take the respective items as morally acceptable without trying to analyze them critically. As shown in the Introduction, this phenomenon happened in other former Communist countries in relation to other EU or international ethical norms on a legislative level; our study suggest the mimesis is also present in younger health professionals, the main reason being fear of breaking the law that, at least in Romania, is often associated with criminal consequences.

Acknowledgment: This work was supported by a grant of the Romanian National Authority for Scientific Research, CNDI- UEFISCDI, project number 215/2012 
Table 1. Genetic Items.

\begin{tabular}{|c|c|c|c|c|c|c|}
\hline \multirow[t]{2}{*}{ Item } & \multirow[t]{2}{*}{ Mean } & \multirow[t]{2}{*}{ Median } & \multirow{2}{*}{$\begin{array}{l}\mathrm{S} \quad \mathrm{t} \quad \mathrm{d} \\
\text { Deviation }\end{array}$} & \multicolumn{3}{|c|}{ Percentiles } \\
\hline & & & & 25 & 50 & 75 \\
\hline $\begin{array}{l}\text { The right to genetic material should be a fundamental human } \\
\text { right }\end{array}$ & 7.65 & 9.00 & 3,2 & 5.50 & 9.00 & 10.00 \\
\hline $\begin{array}{l}\text { Should be allowed genetic engineering techniques that lead to } \\
\text { the elimination of severe diseases such as cystic fibrosis and } \\
\text { thalassemia }\end{array}$ & 8,33 & 10.00 & 2,6 & 8.00 & 10.00 & 10.00 \\
\hline $\begin{array}{l}\text { Should be allowed genetic engineering techniques that lead to } \\
\text { the elimination of diseases such as hypertension and diabetes, } \\
\text { considering that in their pathogenesis also are involved } \\
\text { environmental factors and the side effects of these techniques } \\
\text { are not fully known }\end{array}$ & $3.59^{*-1}$ & 3.00 & 3,3 & .00 & 3.00 & 6.00 \\
\hline $\begin{array}{l}\text { Should be allowed genetic engineering techniques that can } \\
\text { lead to the removal of undesirable traits such as low height or } \\
\text { tendency to gain weight? }\end{array}$ & $1.71^{-5}$ & .00 & 2,5 & .00 & .00 & 3.00 \\
\hline $\begin{array}{l}\text { Should be allowed genetic engineering techniques that lead to } \\
\text { changes of the physical appearance such as a certain color of } \\
\text { the hair or eyes? }\end{array}$ & .86 & .00 & 1,9 & .00 & .00 & 1.00 \\
\hline $\begin{array}{l}\text { Should be allowed genetic engineering techniques that lead to } \\
\text { the augmentation of physical traits such as muscle strength, } \\
\text { vision, hearing }\end{array}$ & $1.17^{*-)}$ & .00 & 2,3 & .00 & .00 & 1.00 \\
\hline $\begin{array}{l}\text { Should be allowed genetic engineering that lead to the } \\
\text { augmentation of psychological traits (intellect, emotional } \\
\text { intelligence)? }\end{array}$ & $1.67^{*-)}$ & .00 & 2,8 & .00 & .00 & 2.50 \\
\hline $\begin{array}{l}\text { Should the State pay through the insurance system genetic } \\
\text { engineering techniques that lead to the augmentation of } \\
\text { physical traits as long-term economic effects will be positive } \\
\text { (healthier person, with decreased healthcare needs, superior } \\
\text { ability to work) }\end{array}$ & 1.43 & .00 & 2,4 & .00 & .00 & 2.00 \\
\hline $\begin{array}{l}\text { Genetic engineering should be allowed only to those who can } \\
\text { pay, as the costs are too high for a public health insurance } \\
\text { system }\end{array}$ & 3.08 & 1.00 & 3,7 & .00 & 1.00 & 6.00 \\
\hline Genetic testing may be available to insurance companies & 2.75 & .00 & 3,6 & .00 & .00 & 5.00 \\
\hline $\begin{array}{l}\text { Genetic tests that could lead to racial discrimination should } \\
\text { be prohibited }\end{array}$ & 5.91 & 5.00 & 3,7 & 3.00 & 5.00 & 10.00 \\
\hline $\begin{array}{l}\text { Information regarding genetic test results should reach other } \\
\text { family members because the genetic material is partially shared }\end{array}$ & 4.31 & 5.00 & 4,0 & .00 & 5.00 & 8.00 \\
\hline
\end{tabular}


New technologies in biomedicine. Opinions of young Romanian physicians - Sorin Hostiuc et al.

Table 2. Reproductive items

\begin{tabular}{|c|c|c|c|c|c|c|}
\hline \multirow[t]{2}{*}{ Items } & \multirow[t]{2}{*}{ Mean } & \multirow[t]{2}{*}{ Median } & \multirow{2}{*}{$\begin{array}{l}\text { S t d d } \\
\text { Deviation }\end{array}$} & \multicolumn{3}{|c|}{ Percentiles } \\
\hline & & & & 25 & 50 & 75 \\
\hline $\begin{array}{l}\text { Sex selection by prenatal screening and selective abortion of } \\
\text { the fetus is morally permissible }\end{array}$ & 0,45 & .00 & 1,5 & .00 & .00 & .00 \\
\hline $\begin{array}{l}\text { Prenatal screening tests should be mandatory because in this } \\
\text { way parents may find out whether their future children has } \\
\text { genetic diseases }\end{array}$ & 7.76 & 10.00 & 3,3 & 6.00 & 10.00 & 10.00 \\
\hline $\begin{array}{l}\text { If prenatal screening identifies a congenital malformation that } \\
\text { would severely affect the child's quality of life, the doctor has a } \\
\text { duty to recommend therapeutic abortion }\end{array}$ & $7.73^{*}$ & 10.00 & 3,2 & 6.00 & 10.00 & 10.00 \\
\hline $\begin{array}{l}\text { Selective abortion for fetal malformation is a light form of } \\
\text { eugenics }\end{array}$ & 6.12 & 7.00 & 3,7 & 3.00 & 7.00 & 10.00 \\
\hline $\begin{array}{l}\text { Psychiatric patients and those with severely diminished mental } \\
\text { capacity should not have the right to reproduce }\end{array}$ & 6.67 & 8.00 & 3,7 & 4.50 & 8.00 & 10.00 \\
\hline
\end{tabular}

Table 3. Cloning items

\begin{tabular}{|c|c|c|c|c|c|c|}
\hline \multirow[t]{2}{*}{ Items } & \multirow[t]{2}{*}{ Mean } & \multirow[t]{2}{*}{ Median } & \multirow{2}{*}{$\begin{array}{l}\mathrm{S} \quad \mathrm{t} \quad \mathrm{d} \\
\text { Deviation }\end{array}$} & \multicolumn{3}{|c|}{ Percentiles } \\
\hline & & & & 25 & 50 & 75 \\
\hline $\begin{array}{l}\text { Therapeutic cloning should be allowed because the benefits are } \\
\text { far greater than the ethical issues generated by the procedure }\end{array}$ & 1.87 & .00 & 2,9 & .00 & .00 & 3.00 \\
\hline $\begin{array}{l}\text { Therapeutic cloning should be allowed only if using animal eggs } \\
\text { in which to insert the human genetic material }\end{array}$ & $.89^{*-}$ & .00 & 2,0 & .00 & .00 & 1.00 \\
\hline Reproductive cloning should be allowed in plants & $2.66^{\cdots}$ & .00 & 3,6 & .00 & .00 & 5.00 \\
\hline $\begin{array}{l}\text { Reproductive cloning of humans should be allowed only if is } \\
\text { used the genetic material of one of the couple who want the } \\
\text { procedure }\end{array}$ & 1.22 & .00 & 2,5 & .00 & .00 & 1.00 \\
\hline Reproductive cloning should be allowed in animals & $1.93^{*-}$ & .00 & 3,2 & .00 & .00 & 2.50 \\
\hline $\begin{array}{l}\text { Cloning and genetic engineering techniques should be banned } \\
\text { as they can be considered as God-like acts }\end{array}$ & 5.20 & 5.00 & 3,8 & 1.00 & 5.00 & 9.00 \\
\hline
\end{tabular}


Table 4 Stem cell items

\begin{tabular}{|c|c|c|c|c|c|c|}
\hline & \multirow[t]{2}{*}{ Mean } & \multirow[t]{2}{*}{ Median } & \multirow{2}{*}{$\begin{array}{l}\mathrm{S} \quad \mathrm{t} \quad \mathrm{d} \\
\text { Deviation }\end{array}$} & \multicolumn{3}{|c|}{ Percentiles } \\
\hline & & & & 25 & 50 & 75 \\
\hline $\begin{array}{l}\text { A couple can give birth to a child in order to collect stem cells } \\
\text { to save the life of a sibling with a severe hematological disease } \\
\text { requiring bone marrow transplant }\end{array}$ & 6.37 & 8.00 & 3,7 & 4.00 & 8.00 & 10 \\
\hline Using stem cells from adults should be allowed & 7.78 & 10.00 & 3,2 & 6.00 & 10 & 10 \\
\hline Creating embryos for stem cell harvesting should be allowed & $2.00^{*}$ & .00 & 3,2 & .00 & .00 & 3.00 \\
\hline Collection of stem cells from aborted embryos should be allowed & $4.95^{* *}$ & 5.00 & 4,2 & .00 & 5.00 & 9.00 \\
\hline $\begin{array}{l}\text { Obtaining stem cells from embryos created by nuclear transfer } \\
\text { techniques, containing strictly genetic material from the person } \\
\text { they were created to benefit, should be allowed }\end{array}$ & $3.24^{*}$ & 1.00 & 3,8 & .00 & 1.00 & 6.50 \\
\hline $\begin{array}{l}\text { The harvesting of cord blood stem cells and their storage in a } \\
\text { stem cell bank should be allowed }\end{array}$ & 9.50 & 10.00 & 1,6 & 10 & 10 & 10 \\
\hline
\end{tabular}

Legend: ${ }^{*}$ - significant negative correlation between the item and age (Spearman), ${ }^{* *}$ - highly significant positive correlation between the item and age (Spearman)

\section{References}

1. Knoppers BM, Chadwick R. Human genetic research: emerging trends in ethics. Nat Rev Genet 2005; 6(1): 75-79.

2. Veerus P, Lexchin J, Hemminki E. Legislative regulation and ethical governance of medical research in different European Union countries. Journal of Medical Ethics 2013.

3. Millard F. Rights Transmission by Mimesis: The Biomedicine Convention in Central Europe. Journal of Human Rights 2010; 9(4): 427-444.

4. Maldonado CE. Crisis of bioethics and bioethics in the midst of crises. Revista Latinoamericana de Bioética 2012; 12(1): 112-123.

5. Hostiuc S. Conventional vs unconventional assisted reproductive technologies: Opinions of young physicians. Journal of Obstetrics \& Gynaecology 2013; 33(1): 67-70.

6. Schifirnet C. Formele fara fond. Un brand romanesc: Constantin Schifirnet; 2007.

7. Maiorescu T. Critice: 1867-1892: Editura libräriei Soccecu \& comp.; 1892.

8. Curca CG. Medicul intre datorie si raspunderea disciplinara si juridica: confidentialitatea informatiei medicale. Revista Romana de Bioetica 2004; 2(4).

9. Curcă G. Aspecte conceptuale privind răspunderea deontologică şi malpractica medicală. Revista Română de Bioetică; 8(1): 51-59.

10. Lundin S. I Want a Baby; Don't Stop Me from Being a Mother: An Ethnographic Study on Fertility Tourism and Egg Trade. Cultural Politics 2012; 8(2): 327-344.

11. Dixon B. Biotech a plus according to European poll. Nature Biotechnology 1991; 9(1): 16.

12. Hampel J, Pfenning U, Peters HP. Attitudes towards genetic engineering. New Genetics and Society 2000; 19(3): 233249.

13. Convention for the Protection of Human Rights and Dignity of the Human Being with regard to the Application of Biology and Medicine: Convention on Human Rights and Biomedicine (1997).

14. Sandel MJ. The case against perfection: Ethics in the age of genetic engineering. Harvard University Press; 2009.

15. Caplan AL. Ethical engineers need not apply: The state of applied ethics today. Science, technology \& Human Values 1980; 5(4): 24-32.

16. Baylis F, Robert JS. The inevitability of genetic enhancement technologies. Bioethics 2004; 18(1): 1-26.

17. Brokaw K. Genetic Screening in the Workplace and Employers' Liability. Colum JL \& Soc Probs 1989; $23: 317$. 
New technologies in biomedicine. Opinions of young Romanian physicians - Sorin Hostiuc et al.

18. Canter EF. Employment discrimination implications of genetic screening in the workplace under Title VII and the Rehabilitation. Act. Am JL \& Med 1984; 10: 323.

19. Hall MA, Rich SS. Laws restricting health insurers' use of genetic information: impact on genetic discrimination. The American Journal of Human Genetics 2000; 66(1): 293-307.

20. Rothstein MA. Genetics and the work force of the next hundred years. Colum Bus L Rev 2000: 371.

21. Lerman C, Hughes C, Lemon SJ, Main D, Snyder C, Durham C, et al. What you don't know can hurt you: adverse psychologic effects in members of BRCA1-linked and BRCA2-linked families who decline genetic testing. Journal of Clinical Oncology 1998; 16(5): 1650-1654.

22. Wijnen JT, Vasen HF, Khan PM, Zwinderman AH, van der Klift H, Mulder A, et al. Clinical findings with implications for genetic testing in families with clustering of colorectal cancer. New England Journal of Medicine 1998; 339(8): 511-518.

23. Offit K, Groeger E, Turner S, Wadsworth EA, Weiser MA. THe "duty to warn" a patient's family members about hereditary disease risks. JAMA 2004; 292(12): 1469-1473.

24. Garel M, Gosme-Seguret S, Kaminski M, Cuttini M. Ethical decision-making in prenatal diagnosis and termination of pregnancy: a qualitative survey among physicians and midwives. Prenatal Diagnosis 2002; 22(9): 811-817.

25. Hostiuc S. Conventional vs unconventional assisted reproductive technologies: Opinions of young physicians. Journal of Obstetrics and Gynaecology 2013; 33(1): 67-70.

26. Hostiuc S, Buda O, Hostiuc M. Late abortion. Attitudes amongst young physicians in Romania. Archives of Gynecology and Obstetrics 2013; 288(2): 431-437.

27. Ballantyne A, Newson A, Luna F, Ashcroft R. Prenatal diagnosis and abortion for congenital abnormalities: is it ethical to provide one without the other? The American Journal of Bioethics 2009; 9(8): 48-56.

28. Hostiuc S, Curca CG. Informed consent in posthumous sperm procurement. Archives of Gynecology and Obstetrics 2010; 282(4): 433-438.

29. Hollá K, Weiss P, Unzeitig V, Cibula D. Abortions and contraception use among Czech and Romanian women: Comparison of representative national studies. The Journal of Sexual Medicine 2011; 8(4): 1083-1091.

30. Cernat V. Ethnic Conflict and Reconciliation in Post-Communist Romania. Peace Psychology in the Balkans. Springer; 2012: 17-34.

31. Cazan R. Constructing Spaces of Dissent in Communist Romania: Ruined Bodies and Clandestine Spaces in Cristian Mungiu's 4 Months, 3 Weeks, and 2 Days and Gabriela Adamesteanu's "A Few Days in the Hospital”. WSQ: Women's Studies Quarterly 2011;39(3): 93-112.

32. Stöbel-Richter Y, Goldschmidt S, Brähler E, Weidner K, Beutel M. Egg donation, surrogate mothering, and cloning: attitudes of men and women in Germany based on a representative survey. Fertility and Sterility 2009; 92(1): 124-130.

33. Katzorke T, Kolodziej FB. Perspektiven eines geänderten Fortpflanzungs-medizingesetzes. Reproduktionsmedizin 2001; 17(6): 325-333.

34. Steinbrook R. The cord-blood-bank controversies. New England Journal of Medicine 2004; 351: 2255-2256.

35. Legea 95 privind reforma în domeniul sănătății, 2006.

36. Bell L, Devaney S. Gaps and overlaps: improving the current regulation of stem cells in the UK. Journal of Medical Ethics 2007; 33(11): 621-622.

37. Board S. Stem cells-scientific, medical, and political issues. The New England Journal of Medicine. 2002; 346(20).

38. Aksoy S. Making regulations and drawing up legislation in Islamic countries under conditions of uncertainty, with special reference to embryonic stem cell research. Journal of Medical Ethics 2005; 31(7): 399-403.

Received: February 14, 2014

Accepted: April 17, 2014 